\title{
Antibacterial activity of essential oils on Xanthomonas vesicatoria and control of bacterial spot in tomato
}

\author{
Gilvaine Ciavareli Lucas(1), Eduardo Alves ${ }^{(1)}$, Ricardo Borges Pereira(2), \\ Fabiano José Perina ${ }^{(1)}$ and Ricardo Magela de Souza(1)
}

(1)Universidade Federal de Lavras, Departamento de Fitopatologia, Caixa Postal 3037, CEP 37200-000 Lavras, MG, Brazil. E-mail: gilciavareli@yahoo.com.br, ealves@ufla.br, perinafj@gmail.com, rmagelas@ufla.br (2)Embrapa Hortaliças, Caixa Postal 218, CEP 70359-970 Gama, DF, Brazil. E-mail: ricardobp@cnph.embrapa.br

\begin{abstract}
The objective of this work was to evaluate the effects of plant essential oils (EOs) on the growth of Xanthomonas vesicatoria, on bacterial morphology and ultrastructure, and on the severity of tomato bacterial spot. EOs from citronella, clove, cinnamon, lemongrass, eucalyptus, thyme, and tea tree were evaluated in vitro at concentrations of $0.1,1.0,10$, and $100 \%$ in $1.0 \%$ powdered milk. The effect of EOs, at $0.1 \%$, on the severity of tomato bacterial spot was evaluated in tomato seedlings under greenhouse conditions. The effects of citronella, lemongrass, clove, and tea tree EOs, at $0.1 \%$, on $X$. vesicatoria cells were evaluated by transmission electron microscopy. All EOs showed direct toxic effect on the bacteria at a $10 \%$-concentration in vitro. Under greenhouse conditions, the EOs of clove, citronella, tea tree, and lemongrass reduced disease severity. EOs of clove and tea tree, and streptomycin sulfate promoted loss of electron-dense material and alterations in the cytoplasm, whereas EO of tea tree promoted cytoplasm vacuolation, and those of citronella, lemongrass, clove, and tea tree caused damage to the bacterial cell wall. The EOs at a concentration of $0.1 \%$ reduce the severity of the disease.
\end{abstract}

Index terms: alternative control of plant disease, cell ultrastructure, pathogenic bacteria.

\section{Atividade antibacteriana de óleos essenciais sobre Xanthomonas vesicatoria e controle da mancha-bacteriana do tomateiro}

\begin{abstract}
Resumo - O objetivo deste trabalho foi avaliar o efeito de óleos essenciais (OEs) no crescimento de Xanthomonas vesicatoria, na morfologia e na ultraestrutura bacteriana, e na severidade da mancha-bacteriana do tomateiro. OEs de citronela, cravo-da-índia, canela, capim-limão, eucalipto, tomilho e árvore-de-chá foram avaliados in vitro nas concentrações de $0,1,1,0,10$ e $100 \%$ em leite em pó a $1,0 \%$. O efeito dos OEs, a $0,1 \%$, na severidade da mancha-bacteriana do tomateiro foram avaliados em plantas de tomateiro em casa de vegetação. Os efeitos dos óleos de citronela, capim-limão, cravo-da-índia e árvore-de-chá, a $0,1 \%$, nas células de $X$. vesicatoria foram avaliados por meio de microscopia eletrônica de transmissão. Todos os OEs apresentaram efeito tóxico direto sobre as bactérias na concentração de $10 \%$ in vitro. Em casa de vegetação, os OEs de cravo-da-índia, citronela, árvore-de-chá e capim-limão reduziram a severidade da doença. Os OEs de cravo-da-índia e árvore-de-chá, e o sulfato de estreptomicina promoveram perda de material eletro-denso e alterações no citoplasma, enquanto o OE de árvore-de-chá promoveu vacuolização do citoplasma, e os de citronela, capim-limão, cravo-da-índia e árvore-de-chá causaram danos à parede celular bacteriana. Os OEs, na concentração de $0,1 \%$, reduzem a severidade da doença.
\end{abstract}

Termos para indexação: controle alternativo de doenças de plantas, ultraestrutura celular, bactéria fitopatogênica.

\section{Introduction}

Diseases of tomato (Solanum lycopersicum L.) are responsible for significant yield losses. Bacterial spot, caused by a number of species of bacteria of the genus Xanthomonas (Dowson) (Jones et al., 2000), is among the most important of these diseases.

Several studies have shown that it is possible to use essential oils to control plant diseases (Pereira et al., 2011). Medicinal plants contain substances that are able to play an important role in plant-pathogen interaction, by activating plant defense mechanisms (Schwan-Estrada et al., 2003; Lucas et al., 2012). Antifungal substances, similar to fungicides, may also be present in those plants, acting directly on the pathogens (Rosato et al., 2007). Medice et al. (2007) observed that essential oils from eucalyptus [Corymbia citriodora (Hook.) K.D.Hill \& L.A.S. Johnson], thyme (Thymus vulgaris L.), neem (Azadirachta indica A. Juss.), and citronella [Cymbopogon nardus (L.) Rendle.] completely inhibited the germination of urediniospores of Asian soybean rust (Phakopsora

Pesq. agropec. bras., Brasília, v.47, n.3, p.351-359, mar. 2012 
pachyrhizi Syd. \& P.Syd.) and reduced the severity of the disease in greenhouse trials. Ranasinghe et al. (2002) reported the fungitoxic and fungistatic activity of the essential oils of clove [Syzygium aromaticum (L.) Merr. \& L.M. Perry] and cinnamon (Cinnamomum zeylanicum Blume) on Colletotrichum musae (Berk. \& M.A. Curtis) Arx, Lasiodiplodia theobromae (Pat.) Griff \& Maubl., and Fusarium proliferatum (Matsush.) Nirenberg. Lucas et al. (2012) found that clove essential oil reduced the severity of tomato bacterial spot and induced an increase in activities of $\beta$-1,3-glucanase, chitinase, and peroxidase.

In an ultra-structural study, Rasooli et al. (2006) showed that the essential oils of Thymus eriocalyx (Ronniger) Jalas and T. x-porlock provoke severe damage to the walls, membranes, and cell organelles of Aspergillus niger spores, when in direct contact, causing morphologic alterations in the hyphae, rupture of the plasma membrane, and mitochondrial destruction.

Researchers have used ATP production in the cell, bacterial mobility, and cationic exchange to evaluate the action of essential oils on bacteria. However, Gustafson et al. (1998) observed, by transmission electron microscopy, that the electron-dense material of Escherichia coli bacteria exposed to the essential oil of tea tree (Melaleuca alternifolia Cheel) was lost, which indicates cell wall loss. In spite of previous research, little is known about the mode of action of these compounds on plant-pathogenic bacteria.

The objective of this work was to evaluate the effect of plant essential oils on the growth of $X$. vesicatoria, on bacterial morphology and ultrastructure, and on the severity of tomato bacterial spot.

\section{Materials and Methods}

The experiments were carried out from January 2008 to December 2010, at the Universidade Federal de Lavras, MG, Brazil. The essential oils of all species used in the experiments were acquired from Brasil Portrait (Sorocaba, SP, Brazil), and the isolate of $X$. vesicatoria used was $89 \mathrm{~T}$, from a culture collection of Embrapa Hortaliças, DF, Brazil.

$X$. vesicatoria was stored at $-80^{\circ} \mathrm{C}$ in glycerolpeptone $\left(15 \% \mathrm{v} \mathrm{v}^{-1}\right)$. The bacterium was streaked into 523 medium (Kado \& Heskett, 1970) and grown at $28^{\circ} \mathrm{C}$ for 24 hours. To confirm the pathogen virulence, the bacterial pathogen was inoculated on healthy plants before every experimental setup. For the experiments, the bacterium was isolated from the previously infected tomato leaves in 523 medium. The inoculum was prepared by soaking the bacterial colony with distilled water, scraping it, and adjusting the concentration to A600 $=0.30\left(5.0 \times 10^{8} \mathrm{CFU} \mathrm{mL}^{-1}\right)$. Inoculation was done by spraying the suspension over tomato plants until runoff.

The direct inhibitory potential of the essential oils on the growth of $X$. vesicatoria was evaluated by in vitro assay. The essential oils of clove, citronella, tea tree, thyme, eucalyptus, cinnamon, and lemongrass (Cymbopogon citratus Stapf) were assessed at concentrations of $0.1,1.0,10$, and $100 \%$ in $1.0 \%$ powdered milk. Powdered milk was used as an emulsifier for the oil-based treatments. The essential oils were added separately to a previously autoclaved powdered milk solution (sterile distilled water + powdered milk) and agitated on a vortex mixer for 10 s. Control treatments with streptomycin sulfate $25 \mathrm{mg} \mathrm{mL}^{-1}$, Recop $2.0 \mathrm{mg} \mathrm{mL}^{-1}$ (a copper fungicide), $1.0 \%$ powdered milk, and sterilized water were also evaluated. The experimental design was a completely randomized block, with four replicates and parcels of six Petri dishes. Previously autoclaved filter paper disks (3.0-micron porosity), with $6.0 \mathrm{~mm}$ in diameter, were soaked in $20 \mu \mathrm{L}$ of each evaluated treatment, dried at room temperature, and distributed in Petri dishes with 523 medium containing $100 \mu \mathrm{L}$ of the $X$. vesicatoria

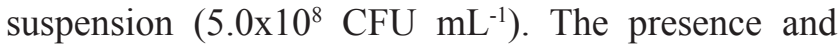
the diameter of inhibition halos were determined 48 hours after incubation in a growth chamber at $28^{\circ} \mathrm{C}$, under a 12-hour photoperiod. Data were subjected to analysis of variance, and means were compared by the Scott-Knott test, at 5\% probability. The SAS software (SAS Institute, 2001) was used for data analysis.

The efficiency of essential oils in reducing the severity of tomato bacterial spot was evaluated. Tomato seedlings of the cultivar Santa Cruz Kada (Hortec, Bragança Paulista, SP, Brazil), susceptible to $X$. vesicatoria, were grown under greenhouse conditions in trays $\left(128\right.$ wells), at $25 \pm 5^{\circ} \mathrm{C}$, with daily irrigation. Fifteen days after sowing, the seedlings were transplanted to $5.0-\mathrm{kg}$ pots containing commercial substrate consisting of expanded vermiculite, organic materials, and macro- and micronutrients. Fertilization was done primarily with $\left(\mathrm{NH}_{4}\right)_{2} \mathrm{SO}_{4}, \mathrm{P}_{2} \mathrm{O}_{5}$, and $\mathrm{KCl}$, according to the necessity of the culture, until the end

Pesq. agropec. bras., Brasília, v.47, n.3, p.351-359, mar. 2012 
of experiment. The experiment was conducted in a randomized complete block design, with five replicates and three plants per plot. Essential oils of thyme, clove, eucalyptus, cinnamon, citronella, tea tree, and lemongrass, at $0.1 \%$ concentration, were used. For all the oil-based treatments, $1.0 \%$ powdered milk was used as an emulsifier. Other additional treatments were: the control (plants sprayed with water); a 1.0\%-powdered milk control; a resistance induction treatment, with acibenzolar-S-methyl $0.2 \mathrm{mg} \mathrm{mL}^{-1}$; and a copper treatment (Recop $2.0 \mathrm{mg} \mathrm{mL}^{-1}$ ).

Three treatment periods were evaluated: tomato plants were treated before pathogen inoculation (B), after pathogen inoculation (A), and with weekly applications, during the entire cultivation period, before and after pathogen inoculation (BA). The B treatment and the first application in the BA treatment were carried out 23 days after sowing, whereas the A treatment took place only 37 days after sowing. All plants were inoculated 30 days after sowing. For inoculation, plants previously exposed to a moisture chamber for 24 hours were used. The concentration of the bacterial suspension used was prepared as described above and adjusted in a spectrophotometer to A600

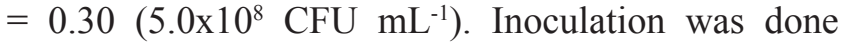
by foliar spray to the point of runoff. Subsequently, plants were exposed to a new moisture chamber for 24 hours. The evaluations began seven days later. Five evaluations of severity were carried out using the Mello disease assessment key (Lobo et al., 2005), and the efficiency of the treatments was calculated by the formula adapted from Abbott (1925): $\mathrm{EF}=(\mathrm{Mtr}-\mathrm{Mte}) /$ (100 - Mte), in which EF is the percentage of treatment efficiency; Mtr is the percentage of treatment severity; and Mte is the percentage of control severity.

Data were subjected to analysis of variance, and means were compared by the Scott-Knott test, at 5\% probability. For data analysis, the software SAS (SAS Institute, 2001) was used.

The effects of essential oils on $X$. vesicatoria cells were evaluated by transmission electron microscopy. The essential oils of citronella, lemongrass, clove, and tea tree at $0.1 \%$ were selected by in vivo assay. Powdered milk at $1.0 \%$ was used as an emulsifier for the oil-based treatments, and streptomycin sulfate $25 \mathrm{mg} \mathrm{mL}^{-1}$ was used as a standard treatment.

The essential oils were added separately to a previously autoclaved powdered milk solution (sterile distilled water + powdered milk) and agitated on a vortex mixer for $10 \mathrm{~s}$. The solution was then added to Erlenmeyer flasks (one of each treatment) containing $100 \mathrm{~mL}$ of liquid 523 medium (Kado \& Heskett, 1970) and $X$. vesicatoria cells at a concentration of $5 \times 10^{8}$ CFU $\mathrm{mL}^{-1}$ previously cultivated in liquid 523 medium, for 24 hours, at $28^{\circ} \mathrm{C}$, under a 12 -hour photoperiod. The Erlenmeyer flasks were maintained in a rotating orbital Table incubator at $100 \mathrm{rpm}$, at $28^{\circ} \mathrm{C}$, under a 12-hour photoperiod, for 24 hours. Then, $2.0-\mathrm{mL}$ aliquots of these solutions were put in microcentrifuge tubes and pre-fixed in a modified Karnovsky solution (glutaraldehyde $2.5 \%$, paraformaldehyde $2 \%$ in sodium cacodylate buffer $0.05 \mathrm{~mol} \mathrm{~L}^{-1}, \mathrm{CaCl}_{2} 0.001 \mathrm{~mol} \mathrm{~L}^{-1}$, $\mathrm{pH}$ 7.2) for 24 hours. The microcentrifuge tubes were centrifuged for $5 \mathrm{~min}$ at $6,000 \mathrm{rpm}$, and the supernatant were discarded. A total of $0.5 \mathrm{~mL}$ of $1.0 \%$ agarose gel ( 50 to $55^{\circ} \mathrm{C}$ ) was added to the microcentrifuge tubes, for the formation of a pellet, on which the bacteria were adhered. Fragments of these pellets with the bacteria were transferred to $0.05 \mathrm{~mol} \mathrm{~L}^{-1}$ of sodium cacodylate buffer solution, washed three times for $10 \mathrm{~min}$, and post-fixed in $1.0 \%$ osmium tetroxide for 1 hour. Later, the fragments were washed twice in distilled water for 15 min, en-bloc stained in $0.5 \%$ uranyl acetate solution for 12 hours, at $4{ }^{\circ} \mathrm{C}$, and washed again in distilled water. The samples were dehydrated in graded acetone series (once at 25, 50, 75, and 90\% and three times at 100\%) and infiltrated in an increasing Spurr/acetone gradient of 30\% (8 hours), $70 \%$ (12 hours) and 100\% twice, for 24 hours each. The specimens were mounted in molds, embedded in pure Spurr resin, and were polymerized in an oven at $70^{\circ} \mathrm{C}$, for 48 hours.

For ultramicrotomy, the blocks obtained were taken to the trimming apparatus for removal of the excess of resin. Afterwards, thick $(0.85 \mu \mathrm{m})$ and thin $(<100 \mathrm{~nm})$ sections were cut, using an ultramicrotome Ultracut, Reichrt-Jung, (Leica, Wetzlar, Germany) equipped with a diamond knife. The thick sections were collected with a gold ring, put on glass slides, stained with toluidine blue ( $1.0 \mathrm{~g}$ toluidine blue, $1.0 \mathrm{~g}$ sodium borate, and $100 \mathrm{~mL}$ water), filtered in a $0.22 \mu \mathrm{m}$ cellulose membrane, and permanently mounted in Permalt medium. The thin sections were picked up on gold slot grids and left to dry on Formvar-coated aluminum racks (Rowley \& Moran, 1975). The sections were post-stained with uranyl acetate, followed by lead citrate for $3 \mathrm{~min}$ each. Then, the samples were examined using a transmission 
electron microscope EM 109, (Zeiss, Oberkochen, Germany) operating at $80 \mathrm{Kv}$ and at a $9-\mathrm{mm}$ distance. The images generated were digitally recorded and edited in the Photopaint software of the Corel Draw 13 package (Corel Corporation, Ottawa, Canada).

\section{Results and Discussion}

None of the essential oils inhibited the growth of $X$. vesicatoria in vitro, at the concentration of $0.1 \%$ (Table 1). At the concentration of $1.0 \%$, the essential oils of thyme, clove, and cinnamon partially inhibited the growth of the bacterium. The other oils did not have any effect on bacterial growth. However, at the concentrations of 10 and $100 \%$ all of the essential oils inhibited bacterial growth. Bacterial growth was observed on sterilized water, Recop, and powdered milk, whereas total bacterial inhibition occurred on streptomycin sulfate. Huang \& Laksman (2010) also observed antibacterial activity of clove oil against seven different species of plant pathogenic bacteria: Agrobacterium tumefaciens, Erwinia carotovora pv. carotovora, Pseudomonas syringae pv. syringae, Ralstonia solanacearum, X. campestris pv. pelargonii, Rhodococcus fascians, and Streptomyces spp. Both Gram-positive and Gram-negative bacteria tested were

Table 1. In vitro growth inhibition of Xanthomonas vesicatoria $(\mathrm{mm})$ subjected to different concentrations of essential oils of cinnamon, citronella, clove, eucalyptus, lemon grass, tea tree, and thyme, and controls treatments powdered milk, Recop, sterilized water, and streptomycin sulfate ${ }^{(1)}$.

\begin{tabular}{lcccc}
\hline Treatment & \multicolumn{4}{c}{ Essential oil concentration (\%) } \\
\cline { 2 - 5 } & 0.1 & 1.0 & 10 & 100 \\
\hline Cinnamon & $0 \mathrm{a}$ & $2 \mathrm{~b}$ & $7 \mathrm{~d}$ & $32 \mathrm{e}$ \\
Citronella & $0 \mathrm{a}$ & $0 \mathrm{a}$ & $2 \mathrm{~b}$ & $39 \mathrm{f}$ \\
Clove & $0 \mathrm{a}$ & $2 \mathrm{~b}$ & $7 \mathrm{~d}$ & $29 \mathrm{~d}$ \\
Eucalyptus & $0 \mathrm{a}$ & $0 \mathrm{a}$ & $3 \mathrm{c}$ & $25 \mathrm{c}$ \\
Lemongrass & $0 \mathrm{a}$ & $0 \mathrm{a}$ & $2 \mathrm{~b}$ & $5 \mathrm{~b}$ \\
Tea tree & $0 \mathrm{a}$ & $0 \mathrm{a}$ & $2 \mathrm{~b}$ & $22 \mathrm{c}$ \\
Thyme & $0 \mathrm{a}$ & $2 \mathrm{~b}$ & $19 \mathrm{e}$ & $39 \mathrm{f}$ \\
Powdered milk $(1.0 \%)^{(2)}$ & $0 \mathrm{a}$ & $0 \mathrm{a}$ & $0 \mathrm{a}$ & $0 \mathrm{a}$ \\
Recop $\left(2.0 \mathrm{mg} \mathrm{mL}^{-1}\right)^{(2)}$ & $0 \mathrm{a}$ & $0 \mathrm{a}$ & $0 \mathrm{a}$ & $0 \mathrm{a}$ \\
Water & $0 \mathrm{a}$ & $0 \mathrm{a}$ & $0 \mathrm{a}$ & $0 \mathrm{a}$ \\
Streptomycin $\left(25 \mathrm{mg} \mathrm{mL}^{-1}\right)^{(2)}$ & $30 \mathrm{~b}$ & $30 \mathrm{c}$ & $30 \mathrm{f}$ & $30 \mathrm{~d}$ \\
\hline CV $(\%)$ & 1.53 & 1.86 & 3.77 & 3.62 \\
\hline
\end{tabular}

${ }^{(1)}$ Means followed by equal letters, in the columns, do not differ by the Scott Knott test, at 5\% probability. ${ }^{(2)}$ The same concentration was used in all treatments without essencial oils addition. sensitive to clove essential oil ( 0.1 and $0.5 \%)$, with $R$. solanacearum being the most sensitive one. Martins et al. (2009) reported the inhibitory effects of citronella in concentrations of $2.0,4.0,8.0$, and $100 \%$, and of lemongrass in concentrations of 1.0, 2.0, 4.0, 8.0, and $100 \%$ on the in vitro development of the bacterium $R$. solanacearum.

In the assay conducted in the greenhouse, no phytotoxicity symptom was observed as a result of applying essential oils. However, there was a significant interaction between the application periods and the products used.

Among the plants sprayed only before inoculation, acibenzolar-S-methyl was the most efficient treatment in controlling the progress of tomato bacterial spot, with $89 \%$ control, followed by the oils of tea tree, lemongrass, clove, citronella, and cinnamon (Figure 1 A). The essential oils of thyme and eucalyptus, and the fungicide Recop were statistically equal to the powdered milk control.

Among the plants sprayed before and after inoculation, acibenzolar-S-methyl was also the most efficient treatment in controlling the disease, with $89 \%$ efficiency, followed by the essential oils of lemongrass, clove, citronella, fungicide, and tea tree (Figure $1 \mathrm{~B}$ ). The essential oils of cinnamon, eucalyptus, and thyme showed lower efficiency, being statistically equal to the powdered milk control (13\%).

Among the plants sprayed only once after inoculation, the fungicide and the essential oils of eucalyptus, citronella, tea tree, lemongrass, and thyme were the best treatments for disease control (Figure $1 \mathrm{C}$ ). Cinnamon oil, acibenzolar-S-methyl, and clove oil did not differ in comparison to the control.

Several works have shown that plant-derived products, such as essential oils, induce resistance in plants (Schwan-Estrada et al., 2003; Lucas et al., 2012). Kessmann et al. (1994) reported that, to be considered resistance inducers, chemical or biological agents should not have direct inhibitory activity on the plant-pathogenic microorganism. However, this concept is currently more flexible, and various compounds that are considered resistance inducers also exert direct action on the pathogens. Active compounds of the oils act directly on the pathogens or induce host resistance through the production of phytoalexins, increased PRP activity, synthesis of structural compounds, and biochemical plant defense (Schwan-Estrada et al., 
2003), resulting in disease reduction (Paul \& Sharma, 2002). Reduction in the severity of the disease was observed at a concentration of $0.1 \%$ of essential oils. This indicates that, besides the induction of resistance, other factors may contribute to a greater effect of the essential oils in vivo than in vitro, such as variation of the optimum temperature of bacterial growth and the presence of microorganisms in the plant surface (Halfeld-Vieira et al., 2004).
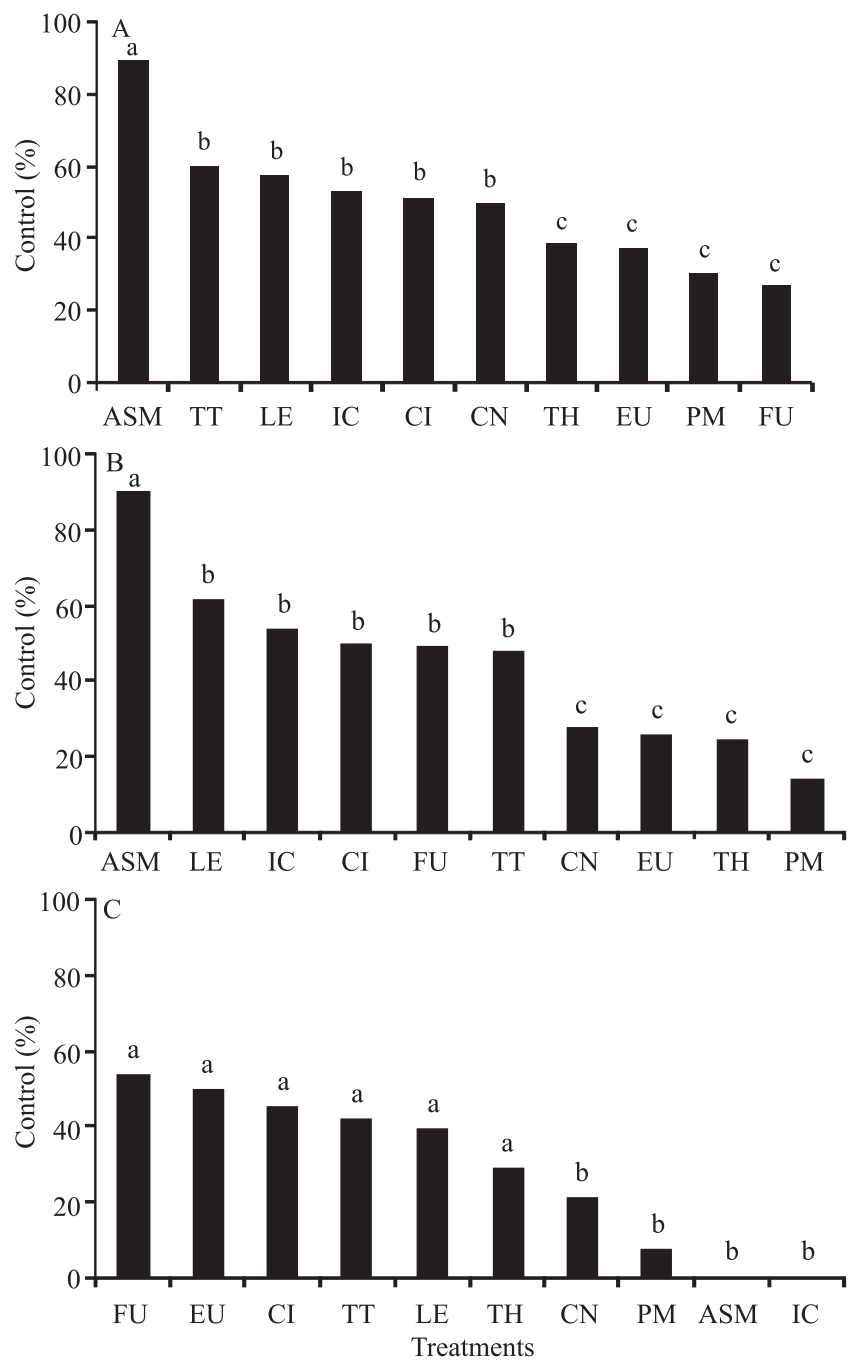

Figure 1. Effectiveness of essential oils at the concentration $0.1 \%$ in the control of tomato bacterial spot in applications before (A), before and after (B), and after (C) inoculation with Xanthomonas vesicatoria. ASM, acibenzolar-S-methyl (0.2 $\left.\mathrm{mg} \mathrm{mL}^{-1}\right)$; TT, tea tree; LE, lemongrass; IC, clove; $\mathrm{CI}$, citronella; $\mathrm{CN}$, cinnamon; $\mathrm{TH}$, thyme; EU, eucalyptus; PM, powdered milk 1.0\%; and FU, Recop $\left(2.0 \mathrm{mg} \mathrm{mL}^{-1}\right)$. Percentage of control was calculated according to formula adapted from Abbott (1925). Means followed by equal letters do not differ by the Scott-Knott test, at 5\% probability.
The efficiency of the oils used in the present study confirms the results obtained by other authors. Abreu (2006) observed reductions of 26,62 , and $95 \%$ in the incidence of tomato black spot in plants treated with the essential oil of cinnamon. In the field, reductions of 12.5 and $32.8 \%$ were observed in the incidence of diseases of tomato plant leaflets treated with the essential oil of cinnamon, at the concentrations of 3,000 and $5,000 \mu \mathrm{L} \mathrm{L}^{-1}(0.3$ and $0.5 \%)$. According to Abreu (2006), increasing the concentration of the essential oil of cinnamon and decreasing the application intervals boosts the efficiency of the oil in controlling the disease. However, in the present study, the essential oil of cinnamon promoted $49 \%$ protection when applied once before inoculation; $21 \%$ protection when applied once after inoculation; and $27 \%$ protection when applied weekly, during the entire cultivation period, before and after inoculation, indicating that decreasing the application intervals did not increase the efficiency of the oil in controlling the disease.

In another study, Medice et al. (2007) observed a reduction in the severity of Asian soybean rust, in cultivars treated with the essential oils of thyme $(0.3 \%)$, citronella $(0.5 \%)$, eucalyptus $(1.0 \%)$, and neem $(1.0 \%)$, seven days before inoculation. In a field experiment with Asian soybean rust and in a greenhouse experiment with coffee plant rust, respectively, Medice et al. (2007) and Pereira et al. (2012) obtained results similar to the ones observed in the present study. The essential oils of tea tree, eucalyptus, and citronella promoted control of the disease similar to that of the fungicide. Furthermore, Pereira et al. (2012) observed protection of $54.3 \%$ when using clove oil $(0.1 \%)$ against coffee plant rust, which is similar to the result found in the present work.

The essential oils of clove, lemongrass, citronella, and tea tree at $0.1 \%$ caused damage to the structure of $X$. vesicatoria cells (Figure 2). All of the evaluated essential oils caused degradation of the cell wall, which was also observed in the bacterial cells exposed to streptomycin sulfate, the antibiotic normally used as a standard in in vitro experiments with bacteria. Alterations in the cytoplasm density, known as electron-dense material loss, were also observed in bacterial cells exposed to the essential oils and to streptomycin sulfate. This can be attributed to cytoplasmic vacuolation, clearly observed in bacterial cells exposed to the essential oil of tea tree (Figure $2 \mathrm{~F}$ ). 
Although essential oils of clove, lemongrass, citronella, and tea tree at $0.1 \%$ did not cause bacterial growth inhibition in vitro, they caused severe damage to the structure of the bacterial cell. As observed in the in vitro assay (Table 1), even the oils at $100 \%$ were not able to completely inhibit $X$. vesicatoria bacterial
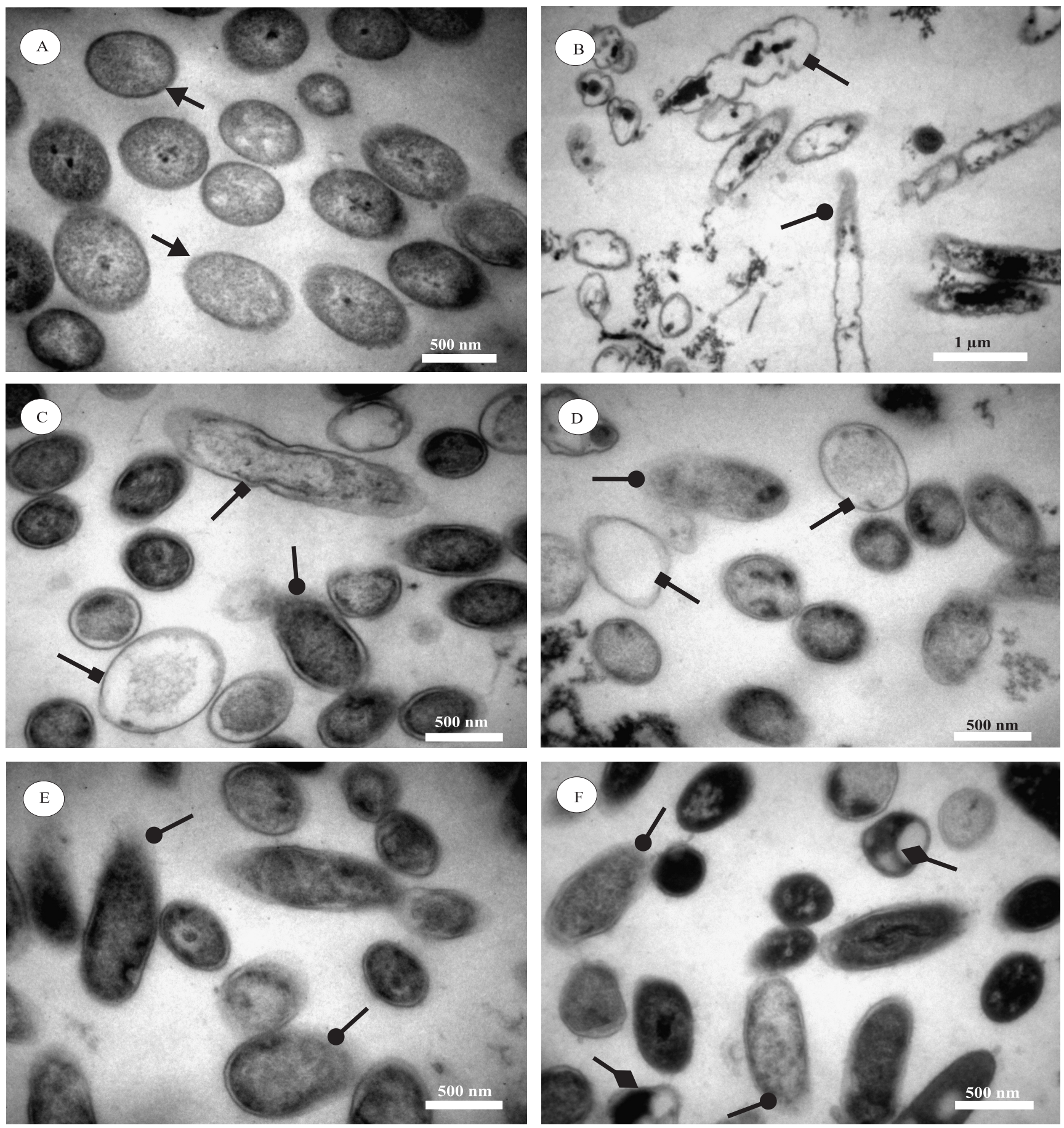

Figure 2. Transmission electron micrographs of Xanthomonas vesicatoria exposed to plant essential oils at the concentration of $0.1 \%$. A, control with complete cell wall (arrows); B, bacterial cells exposed to streptomycin sulfate ( $25 \mathrm{mg} \mathrm{mL}^{-1}$ ); bacterial cells exposed to essential oils of C, clove; D, lemongrass; E, citronella; and F, tea tree, with apparent degradation of the cell wall (arrows with circle), alteration in cytoplasm density (arrows with square), and vacuolation of the cell (arrows with lozenge). 
growth, indicating that some cells remained viable and promoted the multiplication of the bacteria in vitro. According to Hammer et al. (1999), results obtained by different methods may differ, since many factors vary between assays. These factors include differences in microbial growth, exposure of microorganisms to plant oil, oil solubility and components. In the assay using transmission electron microscopy, for example, the contact of the bacteria with the essential oil was direct, due to the liquid medium. For in vitro assay, the diffusion of the essential oils in the lowest concentrations in the solid medium could occur in a heterogeneous form or not occur at all. In this case, the bacteria could not be affected by the essential oil. These results were also observed in other microorganisms (Carson et al., 1995; Piper et al., 2001), indicating the potential use of essential oils in plant pathogen control.

There are few known studies on the antibacterial activity mechanism of the components present in essential oils (Bagamboula et al., 2004; Gill et al., 2006). However, Carson et al. (1995) reported that the essential oil of tea tree can kill a variety of microorganisms (Gram-negative and Gram-positive bacteria, and yeasts), through alterations in the cell membrane structures by disinfectant agents that actively denature the proteins, leading to cytoplasm leakage, lyses, and cell death. Electron-dense material losses and alterations in the cytoplasm density were also observed by Carson et al. (2006) in E. coli cells treated with tea tree essential oil, indicating the loss of cellular constituents and cell wall breakdown. According to Piper et al. (2001), substances present in essential oils, when in contact with microorganisms, affect the integrity of the cell membranes, causing representative cytoplasm extravasations. The loss of electron-dense material was also observed by Gardner \& Peel (1991) in bacteria subjected to disinfectant agents, such as chlorhexidine and quaternary ammonium compounds.

Amaral et al. (2005) evaluated the growth and development of fungi in rice, soy, corn, and bean seeds treated with the essential oil of clove and reported that it possibly acted on the cell wall of the fungus, consequently provoking cell extravasations. In previous works, Blaszyk \& Holley (1998) demonstrated that active eugenol, one of the main compounds in clove oil, had antimicrobial activity on
E. coli and Listeria monocytogenes. Several studies showed that eugenol has an important function in the membrane of microorganisms, including the inhibition of specific processes or cellular enzymes (Walsh et al., 2003).

Ultee et al. (1999) found that the hydrophobic component of carvacrol, another compound present in the essential oil of clove, interacts with the cell membranes of Baccilus cereus, altering the permeability for $\mathrm{H}^{+}$and $\mathrm{K}^{+}$cations. This alteration harms several essential cell processes, such as the inhibition of enzymes by the loss of those ions, the loss of turgidity, the alteration in DNA synthesis, and the reduction of metabolic activities.

There are currently no known reports on the effect of the essential oils of citronella and lemongrass on the ultrastructure of bacterial cells. However, it is believed that their mode of action is similar to that observed in electron micrographs of bacteria treated with the essential oils of tea tree, clove, and glycerol, as shown in this study.

Understanding the action mechanism of these essential oils and their effects on the morphology and physiology of the plant pathogenic bacterium will allow the rational use and the development of alternative methods of plant pathogen control.

\section{Conclusions}

1. Concentrations above $10 \%$ of the essential oils of cinnamon, clove, citronella, tea tree, lemongrass, thyme, and eucalyptus are necessary for in vitro growth inhibition of Xanthomonas vesicatoria; however all essential oils tested, at $0.1 \%$ concentration, are able to reduce the severity of tomato bacterial spot, indicating the existence of other factors influencing the action of essential oils in vivo.

2. Citronella, lemongrass, clove and tea tree essential oils cause loss of integrity of the bacterial cell wall in vitro, which results in various morphological and physiological changes leading to cell death.

\section{Acknowledgments}

To Embrapa Hortaliças and Dr. Alice Quesado-Duval, for making available the bacterial isolate; to Coordenação de Aperfeiçoamento de Pessoal de Nível Superior, for scholarship granted; to Fundação de Amparo à Pesquisa do Estado de Minas 
Gerais, for financial support; and to the Laboratory of Electron Microscopy and Ultrastructural Analysis of Universidade Federal de Lavras, for support.

\section{References}

ABBOTT, W.S. A method of computing the effectiveness of an insecticide. Journal of Economic Entomology, v.18, p.265-267, 1925.

ABREU, C.L.M. Controle de Alternaria solani em tomateiro (Lycopersicon esculentum) com óleos essenciais. 2006. 71p. Tese (Doutorado) - Universidade Estadual Paulista Júlio de Mesquita Filho, Botucatu.

AMARAL, M.F.Z.J.; BARA, M.T.F. Avaliação da atividade antifúngica de extratos de plantas sobre o crescimento de fitopatógenos. Revista Eletrônica de Farmácia, v.2, p.5-8, 2005.

BAGAMBOULA, C.F.; UYTTENDAELE, M.; DEBEVERE, J. Inhibitory effect of thyme and basil essential oils, carvacrol, thymol, estragol, linalool and p-cymene towards Shigella sonnei and Shigella flexneri. Food Microbiology, v.21, p.33-42, 2004.

BLASZYK, M.; HOLLEY, R.A. Interaction of monolaurin, eugenol and sodium citrate on growth of common meat spoilage and pathogenic organisms. International Journal of Food Microbiology, v.39, p.175-183, 1998.

CARSON, C.F.; COOKSON, B.D.; FARRELLY, H.D.; RILEY, T.V. Susceptibility of methicillin-resistant Staphylococcus aureus to the essential oil of Melaleuca alternifolia. Journal of Antimicrobial Chemotherapy, v.35, p.421-424, 1995.

CARSON, C.F.; HAMMER, A.; RILEY, T.V. Melaleuca alternifolia (tea tree) oil: a review of antimicrobial and other medicinal properties. Clinical Microbiology Reviews, v.19, p.50-62, 2006.

GARDNER, J.F.; PEEL, M.M. Principles of chemical disinfection. In: GARDNER, J.F.; PEEL, M.M. Introduction to sterilization, disinfection and infection control. $2^{\text {nd }}$ ed. London: Churchill Livingstone, 1991. p.170-192.

GILL, A.O.; HOLLEY, R.A. Disruption of Escherichia coli, Listeria monocytogenes and Lactobacillus sakei cellular membranes by plant oil aromatics. International Journal of Food Microbiology, v.108, p.1-9, 2006.

GUSTAFSON, J.E.; LIEW, Y.C.; CHEW, S.; MARKHAM, J.; BELL, H.C.; WYLLIE, S.G.; WARMINGTON, J.R. Effects of tea tree oil on Escherichia coli. Letters in Applied Microbiology, v.26, p.194-198, 1998.

HALFELD-VIEIRA, B.A.; ROMEIRO, R.S.; MIZUBUTI, E.S.G. Métodos de isolamento de bactérias do filoplano de tomateiro visando populações específicas e implicações como agentes de biocontrole. Fitopatologia Brasileira, v.29, p.638-643, 2004.

HAMMER, K.A.; CARSON, C.F.; RILEY, T.V. Antimicrobial activity of essential oils and other plant extracts. Journal of Applied Microbiology, v.86, p.985-990, 1999.

HUANG, Q.; LAKSMAN, D.K. Effect of clove oil on plant pathogenic bacteria and bacterial wilt of tomato and geranium. Journal of Plant Pathology, v.92, p.701-707, 2010.
JONES, J.B.; BOUZAR, H.; STALL, R.E.; ALMIRA, E.C.; ROBERTS, P.D.; BOWEN, B.W.; SUDBERRY, J.; STRICKLER, P.M.; CHUN, J. Systematic analysis of xanthomonads (Xanthomonas spp.) associated with pepper and tomato lesions. International Journal of Systematic and Evolutionary Microbiology, v.50, p.1211-1219, 2000.

KADO, C.I.; HESKETT, M.G. Selective media for isolation of Agrobacterium, Corynebacterium, Erwinia, Pseudomonas and Xanthomonas. Phytopathology, v.60, p.96-97, 1970.

KESSMANN, H.; STAUB, T.; HOFMANN, C.; MAETZKE, T.; HERZOG, J. Induction of systemic acquired disease resistance in plants by chemicals. Annual Review of Phytopathology, v.32, p.439-59, 1994.

LOBO, V.L. da S.; GIORDANO, L.B.; LOPES, C.A. Herança da resistência à mancha-bacteriana em tomateiro. Fitopatologia Brasileira, v.30, p.343-349, 2005.

LUCAS, G.C.; ALVES, E.; PEREIRA, R.B.; ZACARONI, A.B.; PERINA, F.J.; SOUZA, R.M. Indian clove essential oil in the control of tomato bacterial spot. Journal of Plant Pathology, v.94, p.45-51, 2012.

MARTINS, E.S.C. da S.; SANTOS, M. da S.; BARROS, H.M.M.; FARIAS, M.A. de A. Atividade antibacteriana de óleos essenciais de citronela, alecrim e erva-cidreira no controle in vitro da bactéria Ralstonia solanacearum em tomateiro. Tecnologia e Ciência Agropecuária, v.3, p.29-34, 2009.

MEDICE, R.; ALVES, E.; ASSIS, R.T. de; MAGNO JÚNIOR, M.R.; LOPES, E.A. das G.L. Óleos essenciais no controle da ferrugem asiática da soja Phakopsora pachyrhizi Syd. \& P. Syd. Ciência e Agrotecnologia, v.31, p.83-90, 2007.

PAUL, P.K.; SHARMA, P.D. Azadirachta indica leaf extract induces resistance in barley leaf stripe disease. Physiological and Molecular Plant Pathology, v.61, p.3-13, 2002.

PEREIRA, R.B.; LUCAS, G.C.; PERINA, F.J.;ALVES, E. Essential oils for rust control on coffee plants. Ciência e Agrotecnologia, v.36, p.16-24, 2012.

PEREIRA, R.B.; LUCAS, G.C.; PERINA, F.J.; RESENDE, M.L.V.; ALVES, E. Potential of essential oils for the control of brown eye spot in coffee plants. Ciência e Agrotecnologia, v.35, p.115-123, 2011.

PIPER, P.; CALDERON, C.O.; HATZIXANTHIS, K.; MOLLAPOUR, M. Weak acid adaptation: the stress response that confers resistance to organic acid food preservatives. Microbiology, V.147, p.2635-2642, 2001.

RANASINGHE, L.; JAYAWARDENA, B.; ABEYWICKRAMA, K. Fungicidal activity of essential oils of Cinnamomum zeylanicum (L.) and Syzygium aromaticum (L.) Merr et L.M. Perry against crown rot and anthracnose pathogens isolated from banana. Letters in Applied Microbiology, v.35, p.208-211, 2002.

RASOOLI, I.; REZAEI, M.B.; ALLAMEH, A. Growth inhibition and morphological alterations of Aspergillus niger by essential oils from Thymus eriocalyx and Thymus x-porlock. Food Control, v.17, p.359-364, 2006.

ROSATO, A.; VITALI, C.; DE LAURENTIS, N.; ARMENISE, D.; ANTONIETTA MILILLO, M. Antibacterial effect of 
some essential oils administered alone or in combination with Norfloxacin. Phytomedicine, v.14, p.727-732, 2007.

ROWLEY, J.C.; MORAN, D.T. A simple procedure for mounting wrinkle-free sections on formvar-coated slot grids. Ultramicrotomy, v.1, p.151-155, 1975.

SAS INSTITUTE. Statistical analysis systems: user's guide. Version 6. Cary: SAS Institute, 2001. 1052p.

SCHWAN-ESTRADA, K.R.F.; STANGARLIN, J.R.; CRUZ, M.E.S. Uso de plantas medicinais no controle de doenças de plantas. Fitopatologia Brasileira, v.28, p.554-556, 2003. Suplemento.

ULTEE, A.; KETS, E.P.W.; SMID, E.J. Mechanisms of action of carvacrol on the food-borne pathogen Bacillus cereus. Applied and Environmental Microbiology, v.65, p.4606-4610, 1999.

WALSH, S.E.; MAILLARD, J.Y.; RUSSEL, A.D.; CATRENICH, C.E.; CHARBONNEAU, D.L.; BARTOLO, R.G. Activity and mechanisms of action of selected biocidal agents on Gram-positive and -negative bacteria. Journal of Applied Microbiology, v.94, p. $240-247,2003$.

Received on October 17, 2011 and accepted on February 17, 2012 